Discussion Paper No. 858

\title{
WIDOW DISCRIMINATION \\ AND FAMILY CARE-GIVING IN INDIA
}

\author{
Yoshihiko Kadoya \\ Ting Yin
}

November 2012

The Institute of Social and Economic Research Osaka University

6-1 Mihogaoka, Ibaraki, Osaka 567-0047, Japan 


\title{
Widow Discrimination and Family Care-Giving in India*
}

\author{
Yoshihiko Kadoya \\ Institute of Social and Economic Research, Osaka University \\ Email: kadoya@iser.osaka-u.ac.jp \\ Ting Yin ${ }^{\dagger}$ \\ Institute of Social and Economic Research, Osaka University \\ Email: yintingjp2001@yahoo.co.jp
}

\begin{abstract}
The purpose of this research is to address the lack of a region-wide view of widow discrimination in India, the home of 42 million widows. This study analyzed the household data collected in face-to-face interviews from January to March of 2011 in six major Indian cities including Delhi, Mumbai, Bangalore, Chennai, Kolkata, and Hyderabad. It was revealed that widow discrimination does not prevail across the nation. That is, this research did not deny the existence of traditional widow discrimination in some areas, but demonstrated that this phenomenon does not represent the whole nation if we focus on the widow's old age and the treatment by their family. Certainly, this research has some limitations, including the fact that the observations came only from cities. However, this is pioneering research, and more significantly, it addresses the lack of a region-wide view analysis of widow discrimination in India with an aging population.
\end{abstract}

Key Words: widowhood, discrimination, family caregiving, India

JEL classification: J16, P48

\footnotetext{
* This research used micro data from the Preference Parameters Study of Osaka University's 21st Century COE Program 'Behavioral Macrodynamics Based on Surveys and Experiments' and its Global COE project 'Human Behavior and Socioeconomic Dynamics.' We acknowledge the program/project's contributors: Yoshiro Tsutsui, Fumio Ohtake, and Shinsuke Ikeda. We thank Charles Yuji Horioka, Midori Wakabayashi, Shizuka Sekita, and the other seminar participants at Osaka University, Japan

†Institute of Social and Economic Research, Osaka University, Mihogaoka 6-1, Ibaraki, Osaka 567-0047, Japan.
} 


\section{Introduction}

Due to longstanding Hindu traditions, many widows have been highly discriminated against in India (Ahmed 2009, Ullrich 1998, Sugirtharajah 2003), which is the home of 42 million widows (Loomba Foundation 2010). However, the argument that widows are discriminated against has relied heavily on case studies in small areas, there is no empirical evidence that such discrimination still exists nationally. Analyzing the household data collected in six major Indian cities, this research addresses the absence of widow discrimination research, with a focus on how widows are treated by their families.

Widow discrimination in India has a long history. According to Ahmad (2009), in ancient Hindu law, the concept of stridharma entails a woman's devotion to her husband. This signifies women's duties, roles, and moral responsibilities. According to this ancient law a husband is a sort of god for women, and in fact Sawaami, the Sanskrit word for husband, means literally "Lord and Master." Families often believe that any "immoral” act by the wife damages her husband's spirit. This was how sati, the Hindu family practice of a widow immolating herself on her husband's funeral pyre, became common in India. The ritual of sati was first reported by Greek travelers to northern India in the 4th century B.C. (Basham, 1954: 187).

Many laws have been passed to prevent people from discriminating against widows. In 1829, during the British colonial period, the British Government banned the ritual of sati. 
More recently, the Indian Government enacted the Commission of Sati (prevention) Act of 1987. After that, the government continued its efforts to toughen the laws against sati until at least 2008 (Ahmed 2009).

According to Ahmed (2009), there are still instances of sati in India. For example, a young widow, aged only 18, was forced to commit suicide after the death of her husband in Rajasthan in 1987. When the case came to trial later, in 1996, the Indian Court upheld her “suicide” as a social tradition and acquitted all 38 defendants who assisted her act. In 2002 a 65-year-old widow committed sati in Madhya Pradesh. And in Utter Pradesh in 2006, a 35-year-old widow died by jumping into the blazing funeral pyre of her husband. Then, in Chhattisgarh in 2008, a 71-year-old widow committed sati.

These well-known cases of sati may only be the tip of the iceberg of widow discrimination in India. Traditionally, those "unfortunate" widows who cannot commit sati are doomed to lead austere lives. According to tradition, they may shave their heads, wear only plain clothing, and eat only a single meal each day, and their presence at family public functions is forbidden (Dandvate, Kumari, \& Verghese, 1989). Many of those who live in joint families die unmourned. For example Vrindavan, a town in northern India, is now home to thousands of destitute widows (Basu 2010). The widows there are often reduced to begging, prostitution, and chanting hymns for up to eight hours in order to earn a handful of lentils and rice (Basu 2010, Ahmed 2009). It can be estimated that a significant number of 
widows are still discriminated against by their families and local communities.

Such discrimination against widows has become a serious social issue as the widow population in India continues to grow at an unprecedented rate. Due to the improvement of healthcare, the average life expectancy in India has increased to 66 years for men and 68 years for women (CIA, 2012). Moreover, the old-age dependent ratio, which is the average ratio of people aged 65 and older to the population aged between 20 and 64 years, is expected to increase from about 10\% in 2000 to about 17\% by 2040 (United Nations 2011). With this trend, the number of widows in India has reached over 40 million, which is about $10 \%$ of the female population in the country (Basu, 2010). Accordingly, with their steadily increasing number, discrimination against widows is a growing concern.

Nonetheless, few researchers have attempted to do a region-wide view analysis of widow discrimination in this era. The research on widow discrimination in India has relied heavily on case studies that focus on specific areas. For example, Ullrich (1998) gathered data about widow discrimination over a 23-year period and analyzed the processes and cultural factors of the issues. However, the data came from a specific village in southern India; therefore the results are not necessarily representative of the entire nation. Likewise, the above-mentioned small town in northern India, Vrindavan, is a popular target area for widow discrimination research. However, the situation in such a "widow town" is an extreme case (Ahmed 2009) and does not represent the entire nation. 
Consequently, the following questions remain unanswered. Are widows in modern India really discriminated against compared to non-widows (i.e., those who are married)? And if so, are there any regional differences? Analyzing the household data collected in six major cities, this research addresses the absence of a region-wide view analysis of widow discrimination in India.

\section{Methods}

Since discrimination occurs within the family, this research focuses on how widows are treated by their families as compared to how non-widows are treated. Specifically, the research investigates whether or not the family takes care of an old widow when she requires long-term care. It is assumed that if widow discrimination exists, a family would only take care of an old woman if she were married. If there is no difference in treatment on the other hand, it can be assumed that widow discrimination does not exist.

\section{Data}

This research utilizes the data of Osaka University’s Global Center of Excellence

(GCOE) Program “Preference Parameter Study of India in 2011.” The study conducted face-to-face interviews of individuals and households in six major cities including Delhi, Mumbai, Bangalore, Chennai, Kolkata, and Hyderabad, from January to March in 2011. The 
target respondents were adults aged 20 to 71 years old. The sampling applied Multi-Stage Sampling and the Allocation Method. The study first divided each city into four sections; north, south, east, and west. Then, each section was further stratified into separate categories according to gender, age group, and socioeconomic characteristics (SEC). Finally, the study set the number of responses to be randomly collected within each stratum. From the data set, the current research chose 794 observations from interviewees who were married and had no missing answers. The distribution of observations by city is 124 (15.62\%) from Delhi, 36 (4.53\%) from Bangalore, 120 (15.11\%) from Mumbai, 195 (24.56\%) from Chennai, 160 (20.15\%) from Kolkata, and 159 (20.03\%) from Hyderabad.

\section{Results}

This research began by investigating family attitudes towards old women in general.

The research first asked whether the mother was a widow. A total of 108 respondents had a widowed mother, whereas 686 respondents had non-widowed mother. The research then asked who does/would primarily take care of his/her mother when the mother requires long-term care.

Tables 1 and 2 illustrate who takes care of the mother in cases where she is a non-widow or a widow, respectively. It can be seen that in both cases the children, including children-in-law, were the primary caregivers for over $80 \%$ of the mothers. For non-widowed 
mothers, the husbands played a very small role in their care. That is, only $3 \%$ of husbands were primary caregivers. As for the widowed-mother, $4.6 \%$ of them had remarried and relied on the new husband for care. In both cases, nearly $100 \%$ of mothers relied on their families rather than long-term care professionals. Overall, there appeared to be little difference between the cases of non-widowed mothers and widowed mothers.

The research further investigated whether or not the family treatment of widows and non-widows varied by city. The model was as follows: Prob (explained_dummy $=1)=\mathrm{a}+\mathrm{b}$ (widow) + c (age) + d (h_income) + e (self_edu $)+$ f (spouse_edu $)+g$ (self_sibling $)+h$ (spouse_sibling) $+\mathrm{i}$ (hindu*widow) $+\mathrm{j}($ Bangalore*widow $)+\mathrm{k}($ Mumbai*widow $)+\mathrm{l}$ $($ Chennai*widow $)+\mathrm{m}($ Kolkata*widow $)+\mathrm{n}($ Hyderabad*widow). Table 3 shows the description of the variables. Numbers 1 through 5 in parentheses are dependent variables. The others are independent variables. Table 4 presents the descriptive statistics.

Overall, there was no evidence that widow discrimination prevails nationally. As seen in the variable "widow" in Table 5, families did not appear to treat widows badly compared with non-widows when it comes to providing long-term care. Indeed, the co-efficient of the variable "widow" was mostly positive. Among widows, financial aid was significantly positive. That is, more families send financial aid to widowed mothers. 
There were some regional differences, but most of them were not significant. Compared to the base variable of Delhi, the people in Chennai appeared to be rather harsh towards widows. The people in Bangalore, on the other hand, seemed to be more thoughtful with respect to widows. Nonetheless, the co-efficient was not significant, except for "aid" in Chennai and "housework” in Bangalore.

Although the sati ritual and related widow discrimination are rooted in the Hindu tradition, Hindus did not necessarily treat widows badly compared with non-widows. Hinduism is still the dominant religion in India, with about $90 \%$ of the people (89\% in this research sample) affiliated with it. However, attitudes may have changed towards widows regardless of religion.

\section{Discussions}

This research addressed the absence of an overview of the national phenomenon of widow discrimination in India, but it had several limitations. First, the data used in this research did not include the observations about widows that had already been sent to "widow town.” The research assumed that the widow (i.e., widowed mother) stayed connected to her family after her husband had passed away. As mentioned earlier, in reality some widows are sent by their families to widow town, where thousands of widows are abandoned. Although 
little evidence of widow discrimination was found in this research, we must recognize that some cases of extreme discrimination still exist.

Second, this research relied heavily on the responses from widows' children. To some extent, children may be reluctant to offer negative responses with regard to their mothers. However, the ritual of sati and related widow discrimination has historically been committed by the family, including the children. Thus, the effect may be limited.

Third, this research assumed that the equal treatment of widows and non-widows in long-term care indicated no discrimination, but that assumption is slightly biased. As widows principally do not have spouses to take care of them, it is natural that other family members provide more care to a widow than to a non-widow. Thus, the treatment of widows compared to non-widows still includes slight discrimination. As seen in Table 1 however, the husband plays a very small role in providing care to his wife in India; therefore the effect may be very limited.

Fourth, the data used in this research was collected in major cities only. For better or for worse, traditional culture tends to remain in rural areas rather than in cities. Although the sample covered many corners of the nation, the sample selection might include city bias. 


\section{Conclusions}

Analyzing the household data collected in face-to-face interviews in six major cities in India, this research revealed that widow discrimination does not prevail across the nation. That is, this research did not deny the existence of traditional widow discrimination in some areas, but instead demonstrated that this phenomenon does not represent the whole nation. Certainly, this research has some limitations, including such that the observations came only from cities. However, this is pioneering research, and more significantly it addresses the lack of a region-wide view analysis of widow discrimination in an India with an aging population. Further research may be needed to understand how widows are treated in families in rural India.

\section{References}

Ahmad, N. (2009). Sati Tradition- Widow Burning in India: A Socio-legal Explanation.

Web Journal of Current Legal Issues, 2009(2). Retrieved from http://webjcli.ncl.ac.uk/2009/issue2/ahmad2.html

Basham, A. L. (1954). The Wonder That Was India. London: Sidgwick and Jackson.

Basu, S. (2010). India's City of Widows. The Guardian. Retrieved from http://www.guardian.co/ul/commentisfree/2010/jun/30/india-city-widows-discrimi nation 
Central Intelligence Agency. (2012). The World Factbook. Retrieved from https://www.cia.gov/library/publications/the-world-factbook/fields/2102.html

Dandvate, P., Kumari, R., \& Verghese, J. (1989). Widows, abandoned and destitute women in India. New Delhi: Radiant Publishers.

Ullich, H. E. (1988). Widows in a South India Society: Depression as an Appropriate Response to Cultural Factors. Sex Roles, 19 (3/4), 169-188.

Sugirtharajah, S. (2003). Imagining Hinduism: A Postcolonial Perspective. London: Routledge.

Loomba Foundation (2011). Educate a Widows Child Documentary. Retrieved from http://www.theloombafoundation.org/

United Nations (2011). World Population Prospects. Retrieved from http://esa.un.org/wpp/panel_population.htm 
Table 1: Primary caregiver for the non-widowed mother when she needs long-term care.

\begin{tabular}{|l|c|c|c|}
\hline & Freq. & Percent & Cum. \\
\hline 1. You (i.e., child) & 74 & 15.8 & 15.80 \\
\hline 2. Your spouse & 48 & 9.98 & 25.78 \\
\hline 3. Your brother/sister or your spouse's brother/sister & 251 & 52.18 & 77.96 \\
\hline 4. The spouse of the parent requiring care & 15 & 3.12 & 81.08 \\
\hline 5. Other family member & 85 & 17.67 & 98.75 \\
\hline 6. Nursing home or assisted living home & 2 & 0.42 & 99.17 \\
\hline 7. Home helper & 3 & 0.62 & 99.79 \\
\hline 8. Other & 1 & 0.21 & 100.00 \\
\hline Total & 481 & 100.00 & \\
\hline
\end{tabular}


Table 2: Primary caregiver for the widowed mother when she needs long-term care

\begin{tabular}{|l|c|c|c|}
\hline & Freq. & Percent & Cum. \\
\hline 1. You (child) & 21 & 19.44 & 19.44 \\
\hline 2. Your spouse & 12 & 11.11 & 30.56 \\
\hline 3. Your brother/sister or your spouse's brother/sister & 57 & 52.78 & 83.33 \\
\hline 4. The spouse of the parent requiring care & 5 & 4.63 & 87.96 \\
\hline 5. Other family member & 12 & 11.11 & 99.07 \\
\hline 6. Nursing home or assisted living home & 1 & 0.93 & 100.00 \\
\hline 7. Home helper & - & - & \\
\hline 8. Other & - & - & \\
\hline Total & 108 & 100.00 & \\
\hline
\end{tabular}


Table 3: Variables and Descriptions

\begin{tabular}{|c|c|}
\hline Variable & Description \\
\hline (1) live_together & $\begin{array}{l}\text { Do/Would you and/or your spouse live with your mother when she needs long-term care? (Yes } \\
=1, \text { No }=0 \text { ) }\end{array}$ \\
\hline (2) neighbor & $\begin{array}{l}\text { Do/Would you and/or your spouse live close to your mother when she needs long-term care? } \\
(\text { Yes }=1 \text {, No }=0)\end{array}$ \\
\hline (3) housework & $\begin{array}{l}\text { Do/Would you and/or your spouse help your mother with housework when she needs } \\
\text { long-term care? (Yes = } 1, \text { No }=0 \text { ) }\end{array}$ \\
\hline (4) care & $\begin{array}{l}\text { Do/Would you and/or your spouse provide care for your mother when she needs long-term } \\
\text { care? }\left(\text { Yes }=1, N_{0}=0\right)\end{array}$ \\
\hline (5) aid & $\begin{array}{l}\text { Do/Would you and/or your spouse provide financial assistance to your mother when she needs } \\
\text { long-term care? }(\text { Yes }=1, \mathrm{No}=0)\end{array}$ \\
\hline widow & Is your mother a widow? $($ Yes $=1, \mathrm{No}=0)$ \\
\hline age & Your age \\
\hline h_income & Your annual household income (Rs) \\
\hline self_edu & Your schooling year \\
\hline spouse_edu & Your spouse’s schooling year \\
\hline self_sibling & \# of siblings (you) \\
\hline spouse_sibling & \# of siblings (your spouse's) \\
\hline hindu & Religious affiliation (Hindu = 1, Others $=0$ ) \\
\hline Delhi & City dummy \\
\hline Bangalore & City dummy \\
\hline Mumbai & City dummy \\
\hline Chennai & City dummy \\
\hline Kolkata & City dummy \\
\hline Hyderabad & City dummy \\
\hline
\end{tabular}


Table 4: Descriptive Statistics

\begin{tabular}{|c|c|c|c|c|c|}
\hline & Mean & Sd. & Min & Max & Obs \\
\hline (1) live_together & 0.1561713 & 0.3632465 & 0 & 1 & 794 \\
\hline (2) neighbor & 0.1309824 & 0.3375937 & 0 & 1 & 794 \\
\hline (3) housework & 0.1801008 & 0.3845136 & 0 & 1 & 794 \\
\hline (4) care & 0.2329975 & 0.423071 & 0 & 1 & 794 \\
\hline (5) aid & 0.181302 & 0.3855592 & 0 & 1 & 794 \\
\hline widow & 0.1360202 & 0.343026 & 0 & 1 & 794 \\
\hline age & 46.4005 & 12.6108 & 22 & 71 & 794 \\
\hline $\mathrm{h}$ _income & 179194 & 175746.6 & 24000 & 3500000 & 794 \\
\hline self_edu & 9.243073 & 4.649111 & 0 & 18 & 794 \\
\hline spouse_edu & 9.239295 & 4.626332 & 0 & 18 & 794 \\
\hline self_sibling & 2.953401 & 1.713118 & 0 & 9 & 794 \\
\hline spouse_sibling & 2.770781 & 1.699448 & 0 & 9 & 794 \\
\hline Hindu*widow & 0.1183879 & 0.3232705 & 0 & 1 & 794 \\
\hline Delhi*widow (base) & 0.0151134 & 0.1220807 & 0 & 1 & 794 \\
\hline Bangalore*widow & 0.138359 & 0.1169581 & 0 & 1 & 794 \\
\hline Mumbai*widow & 0.0264484 & 0.1605656 & 0 & 1 & 794 \\
\hline Chennai*widow & 0.0352645 & 0.184638 & 0 & 1 & 794 \\
\hline Kolkata*widow & 0.0403023 & 0.1967912 & 0 & 1 & 794 \\
\hline Hyderabad*widow & 0.0050378 & 0.070843 & 0 & 1 & 794 \\
\hline
\end{tabular}


Table 5: Estimation Results

\begin{tabular}{|c|c|c|c|c|c|}
\hline & $\begin{array}{c}(1) \\
\text { live_together }\end{array}$ & $\begin{array}{c}\text { (2) } \\
\text { neighbor }\end{array}$ & $\begin{array}{c}\text { (3) } \\
\text { housework }\end{array}$ & $\begin{array}{l}\text { (4) } \\
\text { care }\end{array}$ & $\begin{array}{l}(5) \\
\text { aid }\end{array}$ \\
\hline widow & $\begin{array}{l}0.755 \\
(1.33)\end{array}$ & $\begin{array}{l}-0.344 \\
(-0.47)\end{array}$ & $\begin{array}{l}0.457 \\
(0.78)\end{array}$ & $\begin{array}{l}0.509 \\
(0.98)\end{array}$ & $\begin{array}{l}1.672^{* *} \\
(2.64)\end{array}$ \\
\hline age & $\begin{array}{c}-0.00613 \\
(-1.32)\end{array}$ & $\begin{array}{c}-0.0179^{* * *} \\
(-3.39)\end{array}$ & $\begin{array}{c}-0.00978^{*} \\
(-2.21)\end{array}$ & $\begin{array}{c}-0.0112^{* *} \\
(-2.67)\end{array}$ & $\begin{array}{r}-0.0102^{*} \\
(-2.23)\end{array}$ \\
\hline h_income & $\begin{array}{c}0.000000303 \\
(0.99)\end{array}$ & $\begin{array}{c}-0.00000116 \\
(-1.79)\end{array}$ & $\begin{array}{c}-2.15 e-08 \\
(-0.06)\end{array}$ & $\begin{array}{c}-0.000000573 \\
(-1.33)\end{array}$ & $\begin{array}{c}-0.000000168 \\
(-0.43)\end{array}$ \\
\hline self_edu & $\begin{array}{c}0.0629^{* * *} \\
(4.12)\end{array}$ & $\begin{array}{c}0.00885 \\
(0.56)\end{array}$ & $\begin{array}{c}0.0617^{* * *} \\
(4.23)\end{array}$ & $\begin{array}{c}0.0369^{* *} \\
(2.74)\end{array}$ & $\begin{array}{c}0.0350^{*} \\
(2.43)\end{array}$ \\
\hline spouse_edu & $\begin{array}{c}-0.0557^{* * *} \\
(-3.79)\end{array}$ & $\begin{array}{l}0.0266 \\
(1.61)\end{array}$ & $\begin{array}{c}-0.0313^{*} \\
(-2.21)\end{array}$ & $\begin{array}{c}0.000590 \\
(0.04)\end{array}$ & $\begin{array}{c}-0.0194 \\
(-1.38)\end{array}$ \\
\hline sibling_self & $\begin{array}{c}-0.0159 \\
(-0.45)\end{array}$ & $\begin{array}{l}0.0187 \\
(0.47)\end{array}$ & $\begin{array}{l}-0.0438 \\
(-1.25)\end{array}$ & $\begin{array}{c}-0.0124 \\
(-0.39)\end{array}$ & $\begin{array}{l}0.0209 \\
(0.61)\end{array}$ \\
\hline sibling_spouse & $\begin{array}{c}0.0532 \\
(1.54)\end{array}$ & $\begin{array}{l}-0.0431 \\
(-1.06)\end{array}$ & $\begin{array}{l}0.0507 \\
(1.49)\end{array}$ & $\begin{array}{l}0.0358 \\
(1.15)\end{array}$ & $\begin{array}{c}0.116^{* * *} \\
(3.40)\end{array}$ \\
\hline hindu*widow & $\begin{array}{l}0.0694 \\
(0.15)\end{array}$ & $\begin{array}{l}0.124 \\
(0.22)\end{array}$ & $\begin{array}{l}-0.298 \\
(-0.61)\end{array}$ & $\begin{array}{l}-0.210 \\
(-0.51)\end{array}$ & $\begin{array}{l}-0.347 \\
(-0.61)\end{array}$ \\
\hline Bangalore*widow & $\begin{array}{l}0.453 \\
(0.82)\end{array}$ & $\begin{array}{l}0.504 \\
(0.72)\end{array}$ & $\begin{array}{l}1.166^{*} \\
(2.00)\end{array}$ & $\begin{array}{l}0.860 \\
(1.55)\end{array}$ & $\begin{array}{l}0.340 \\
(0.60)\end{array}$ \\
\hline Mumbai*widow & $\begin{array}{l}-0.996 \\
(-1.80)\end{array}$ & $\begin{array}{l}1.596^{* *} \\
(2.58)\end{array}$ & $\begin{array}{l}-0.280 \\
(-0.52)\end{array}$ & $\begin{array}{l}-0.279 \\
(-0.57)\end{array}$ & $\begin{array}{l}- \\
-\end{array}$ \\
\hline Chennai*widow & $\begin{array}{l}-0.741 \\
(-1.51)\end{array}$ & $\begin{array}{c}-0.0790 \\
(-0.12)\end{array}$ & $\begin{array}{l}-0.307 \\
(-0.59)\end{array}$ & $\begin{array}{l}-0.760 \\
(-1.50)\end{array}$ & $\begin{array}{c}-1.444^{* *} \\
(-2.86)\end{array}$ \\
\hline Kolkata*widow & $\begin{array}{l}0.0501 \\
(0.11)\end{array}$ & $\begin{array}{l}- \\
-\end{array}$ & $\begin{array}{l}-0.722 \\
(-1.32)\end{array}$ & $\begin{array}{l}0.234 \\
(0.53)\end{array}$ & $\begin{array}{l}-0.641 \\
(-1.44)\end{array}$ \\
\hline Hyderabad*widow & $\begin{array}{l}-0.428 \\
(-0.51)\end{array}$ & $\begin{array}{l}0.643 \\
(0.73)\end{array}$ & $\begin{array}{l}0.0386 \\
(0.05)\end{array}$ & $\begin{array}{l}-0.226 \\
(-0.29)\end{array}$ & $\begin{array}{l}-0.240 \\
(-0.32)\end{array}$ \\
\hline _cons & $\begin{array}{c}-1.080^{* * *} \\
(-3.36) \\
\end{array}$ & $\begin{array}{l}-0.437 \\
(-1.23) \\
\end{array}$ & $\begin{array}{l}-0.798^{* *} \\
(-2.60)\end{array}$ & $\begin{array}{l}-0.580^{*} \\
(-2.01)\end{array}$ & $\begin{array}{c}-1.059^{* * *} \\
(-3.42) \\
\end{array}$ \\
\hline$N$ & 794 & 762 & 794 & 794 & 773 \\
\hline
\end{tabular}

